\title{
PRZEDMOWA AUTORA
}

W czasie szkolenia kwalifikatorów, producentów nasion, a także studentów, często zwracano się do mnie z prośbą o opracowanie kolorowych tablic chwastów występujących na plantacjach nasiennych, a rozmnażających się przez nasiona, oraz o podanie przy tym opisu tych chwastów, ich występowania oraz sposobów zwalczania. Życzeniu temu, wprawdzie z lekkim wahaniem, postanowiłem zadośćuczynić. Zdecydowałem się na to, pomimo ukazania się już wielu nowych książek, omawiających chwasty polowe i ich zwalczanie.

$\mathrm{Na}$ pewno nawet wykwalifikowanemu rolnikowi nie jest łatwo rozpoznawać rośliny na podstawie czarno-białych rysunków, a $\mathrm{z}$ pewnością duże trudności sprawia mu także wyobrażenie sobie naturalnej wielkości roślin podanych na rysunkach w niejednolitej skali. W tej książce podjąlem próbę wyeliminowania tych trudności. Podobne rośliny, o ile było to możliwe, zostały przedstawione na jednej tablicy, wszystkie w jednakowym zmniejszeniu, a najważniejsze części roślin, na przykład nasiona, narysowano na milimetrowej siatce $(5 \times 5 \mathrm{~mm})$, dzięki czemu nawet przy niejednakowym powiększeniu tych części można od razu poznać ich naturalną wielkość.

Jeżeli udało mi się $\mathrm{w}$ pewnym stopniu ułatwić rolnikom i uczącej się młodzieży wiejskiej rozpoznawanie najważniejszych chwastów nasiennych oraz wyjść naprzeciw dążeniom zmierzającym do podniesienia plonów nasion, które obecnie zawierają duże domieszki nasion chwastów, to opracowanie tej książki jest całkowicie usprawiedliwione, a cel jej osiągnięty.

Tablice 8 i 13 wykonała z natury dyplomowana kreślarka p. Christine Hessel, a wszystkie pozostałe - dyplomowana kreślarka p. Ute Herrmann. Obu paniom chciałbym na tym miejscu jeszcze raz podziękować.

Przy wyborze chwastów i roślin uprawnych kierowałem się jedynie znaczeniem poszczególnych gatunków, występujących jako chwasty lub jako obce gatunki uprawne na plantacjach nasiennych i w zasiewach roślin pastewnych. Nie uwzględniłem więc chwastów ṇasiennych zasadniczo nie występujących w materiałach siewnych lub calkowicie dających się oddzielać w procesie czyszczenia nasion, nawet takich, jak żółtlica drobnokwiatowa (Galinsoga parviflora Cav.), rozmaite gatunki rodzajów Sonchus, Cirsium i Carduus oraz wiele innych, które $\mathrm{z}$ powodu masowego występowania w uprawach polowych zasługują na szczególną uwagę przy zwalczaniu chwastów.

Ażeby nie utrudniać rolnikom-praktykom korzystania $\mathrm{z}$ tej książki, całkowicie pominąlem omawianie literatury. Wykaz literatury chwastów znajduje 
się w załączniku. Dane dotyczące zwalczania poszczególnych chwastów czerpałem z prac Rademachera (96), Linsera i Frohnera (71), Grossmanna (28), Rademachera i Flocka (99), Schmidta (106) oraz z podstawowych prac Wehsarga (124), Petersena (87) i Korsmo (56); wykorzystałem również wyniki badań własnych i przemysłu chemicznego.

Jako uzupełnienie wiadomości o samych chwastach i roślinach stanowiących domieszki obcouprawne wydawało mi się konieczne i celowe, chociaż powszechnie nie przyjęte, omówienie uszkodzeń i strat materiału siewnego powstających w czasie młocki i czyszczenia. Opracowanie poświęcone temu tematowi było potrzebne, ponieważ w czasie młócenia traw i bukowania koniczyn powstają znaczne straty, których można uniknąć; postanowiłem więc skorzystać z okazji i udowodnić producentom nasion, że szkody te mogą być mniejsze. Niektóre tabele włączono, aby podać studiującej młodzieży wiadomości brakujące w innych książkach.

We wszystkich państwach świata chwasty corocznie zmniejszają wartość zbieranych plonów o wiele miliardów marek niemieckich. Trudno ocenić również nakłady pracy poświęcanej co roku zwalczaniu chwastów oraz koszty środków chemicznych corocznie stosowanych. Tylko dokładna znajomość poszczególnych gatunków chwastów, ich biologii i wymagań pozwoli na skuteczne ich zwalczanie oraz zapewni uzyskiwanie odpowiednich efektów w produkcji roślinnej, zwłaszcza w produkcji nasiennej przy niewielkich nakładach; pragnąłbym, aby do tego mogła dopomóc niniejsza książka.

W tym miejscu chciałbym złożyć specjalne podziękowanie Zjednoczeniv Państwowych Gospodarstw Nasiennych i jego naczelnemu dyrektorowi Panu G. Koehlerowi za pomoc finansową udzieloną na wydanie tej książki, co umożliwiło wydanie jej w pięknej formie po stosunkowo niskiej cenie.

Autor

Paulinenaue, wiosna 1961 